\title{
EFFICACY OF DORAMECTIN, CLOSANTEL AND IVERMECTIN IN THE TREATMENT OF TICK INFESTATION AMONG ZOO ANIMALS
}

\author{
K. Nalini Kumari and P.C. Choudhuri
}

Department of Medicine, College of Veterinary Science, Tirupati, Andhra Pradesh 517502, India

\section{Introduction}

In wild animal practice tick infestation is not as commonly encountered as internal parasitism. Ticks transmit several infectious diseases, suck blood and cause discomfort. In old, debilitated and very young animals, severe tick infestation may cause anemia, paralysis and even death. For treating tick infestation in wildlife, the same drugs that are used for domestic animals are of value. This report describes successful treatment of a few clinical cases of tick infestation of varied severity in wild carnivores using endectocides like Doramectin, Closantel and Ivermectin.

\section{History and Observations}

In S.V.Zoological Park, Tirupati, two Wolves (1 male, 1 female, 810 yrs, body weight $20 \mathrm{~kg}$.) three male Wolf cubs (2 months, body weight $2.5 \mathrm{~kg}$.) three Dholes (2 females, 1 male, 3-4 yrs, body weight $20 \mathrm{~kg}$.) and four Leopards ( 2 males, 2 females, 4-10 yrs, body weight $50-100 \mathrm{~kg}$ ) were reported to be infested with ticks. Clinical examination of Wolf cubs revealed severe infestation with ticks which were in bunches around the eyes and margin and opening of the ear canal and the interdigital space. The other parts of the body which were also affected in decreasing order of severity were groin, tail, neck and back. The cubs were very dull, weak, anaemic, unable to move and were lying down lethargically even after being approached. The Wolves had a moderate infestation and were weak while the Dholes and Leopards were affected mildly without any apparent clinical symptoms.

\section{Results}

The Wolves and their cubs were given a single injection of a new endectocide i.e. Doramectin (Dectomax, M/S Pfizer Animal

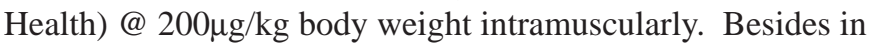
such areas as pinnae of ears and interdigital space, where ticks were in layers one over the other, manual removal of some was carried out after applying dilute deltamethrin solution. The kennels and night house were exposed to blow lamp and the entire enclosure area including the pasture was set on fire. It was observed that after 24 hours of administration of Doramectin almost all the ticks died and dropped on the floor while very few paralysed ticks were still on the body which were shed off by the second day. The Wolves were free from ticks during the period of 14 days of confinement in the kennels. But upon their release into the enclosures, they were reinfested with very few ticks after four days. The burrows were filled tightly with mud and reinforced with heavy stones to prevent the wolves from digging them again. Subsequently even the reinfested ticks shed off in two days without any further treatment. The wolf cubs were also given two doses of parenteral iron dextran at weekly intervals.

Dholes were given closantel orally along with meat @ 1m1/15 kg.body weight and the Leopards were given invermectin@ $200 \mu \mathrm{g} / \mathrm{kg}$ body weight, subcutaneously, keeping them in a squeeze cage. A single administration of both these drugs brought complete relief by the second day of administration.

\section{Discussion}

Doramectin, a recently introduced endectocide has been successfully used in the control of ectoparasitic infestation in pet dogs (Jagannath \& Yathiraj, 1999) but there is no report on its use in wild carnivores. Hence this drug was tried and found to be quite effective and safe as no adverse reaction was noticed even in weak and young Wolf cubs. Doramectin derived from Streptomyces avermitilis inhibts the electrical activity of nerve cells and causes paralysis and death of parasites (Turner \& Schaeffer, 1990) as has been recorded in this study. But the Wolves developed mild tick reinfestation as the burrows of the enclosure in which they took shelter were found to be intensely infested with ticks which could not be cleared by external fire. However, maintenance of higher plasma Doramectin level for 38-45 days (Jones et al., 1993) might have made the Wolves to completely recover from the mild reinfestation.

Closantel (Exi not, M/s Cadia Pharmaceuticals, Vet. Div.), a new oral endectocide has been tried in domestic animals earlier and was found to be effective and safe in Dholes. It can be used as a routine dewormer which may also get rid of the ectoparasitic infestation. Ivermectin (Ivomee, M/s Dynamic Pharmaceuticals) a widely used drug proved to be efficaceous in Leopards. Chakravarthy and Malhotra (1975) reported tick infestation in a Lesser Panda and Jaguar and their treatment with malathion 
spray.

\section{Acknowledgements}

The authors are thankful to Dr. K.V. Ramana, in-charge Veterinarian and Sri. Parthasarathi, Assistant Curator of S.V. Zoological Park, Tirupati for their cooperation.

\section{References}

Chakravarthy, I.B. and A.K. Malhotra (1975). A note on Rhipi- cephalus sanguineus (Latr) infestation of Lesser Panda (Ailurus fulgens) and Jaguar (Panthera onca). Indian Vet. J. $52: 9$ (730)

Jaganath, M.S. and S. Yathiraj (1999). Clinical evaluation of Doramectin. Indian Vet. J. 76: 4(333-334).

Jones, R.M., N.B. Logan., A.J. Weatherley, A.S. Little and C.D. Smoothers (1993). Activity of doramectin against nematode endoparasites of cattle. Vet. Parasitology. 49: 1 (27-37).

Turner, $M$ and Schaeffer, (1990). Mode of action of ivermectin. In: Ivermectin and Abamectin, ed. W.C. Cambell. pp. 51-59. SpringerVerlag, New York.

\title{
PROBLEMS FOR BEEKEEPING IN BAHRAIN (ARABIAN GULF)
}

\author{
R.N.S. Kushwah ${ }^{1}$ and Jasvir Singh ${ }^{2}$ \\ ${ }^{1}$ Speedy Motor Service, PO Box 800, HQ-Isa Town, Manama,State of Bahrain (Arabian Gulf). \\ ${ }^{2}$ Entomology Research Unit, School of Student in Zoology, Jiwaji University, Gwalior, Madhya Pradesh 474 011, India (present address of RNSK)
}

\section{Introduction}

Beekeeping is the practice of keeping and/or manipulating honeybees for the production of honey, wax, propolis, pollen, royal jelly and beevenom. Besides this, honeybees are highly efficient pollinators. Before developing an infrastructure for beekeeping in a particular vicinity, it is important to recognize the problems to be faced during and after establishment of beekeeping industry. The present work deals with such problems identified in Bahrain for developing its beekeeping industry.

\section{Study Area}

The present work was carried out on Bahrain Island and neighbouring islands such as Muharraq, Sitrah, Nabih Salih, Umm Na'san and Zallaq.

The state of Bahrain is situated at a latitude of circa. $26^{\circ} \mathrm{N}$ and a longitude of 50 $30^{\prime} \mathrm{E}$, in the Arabian (Persian) Gulf between the north eastern coast of Saudi Arabia and the Qatar Peninsula. Bahrain has a total land area of 690.86 sq.km. (Doorankamp et. al., 1980; CSO 1986; Phillips, 1986). Bahrain Island, from which the country takes its name, represents 85 per cent of the total land area. The Bahrain Island is about $48 \mathrm{~km}$. long and $16 \mathrm{~km}$. wide at its widest point. The other islands surrounding Bahrain are now connected by causeways.

\section{Methods}

With the help of map obtained from CSO, 1997 detailed surveys have been made in the study area to collect information on honeybee habitat structure, crop patterns, floral characteristics, resource partitioning, etc. Questionnaires were prepared and data was collected during the surveys according to the methods adopted by Rao and Agrawal, 1998. Information on crop patterns, area under cultivation and agricultural practices were collected from the Ministry of Agriculture and Works, The Central Statistics Organisation, Bahrain, and meteorological data was obtained form the Meteorological Laboratory, Bahrain Defence Force (BDF).

\section{Results and Discussion}

Adverse climatic conditions

Owing to the proximity of Bahrain to the tropics, the temperature range is very wide. The temperatures reported from Muharraq varies from a daily mean maximum of $40^{\circ} \mathrm{C}$ in August to a daily mean minimum of $14^{\circ} \mathrm{C}$ in January (CSO, 1997). This high range of temperature acts as a limiting factor for the foraging activity of the bees. During higher temperature periods the bees have to expend a major part of their energies to cool the nest by collecting more water rather than in gathering nectar and pollen. 